\title{
Herbaceous Understorey: An Overlooked Player in Forest Landscape Dynamics?
}

\author{
Timothy Thrippleton, ${ }^{1 *}$ Harald Bugmann, ${ }^{1}$ Kathrin Kramer-Priewasser, ${ }^{2}$ \\ and Rebecca S. Snell ${ }^{1}$
}

${ }^{1}$ Department of Environmental Systems Science, Forest Ecology, Swiss Federal Institute of Technology, ETH Zurich, Universitätstrasse 16, 8092 Zürich, Switzerland; ${ }^{2}$ Swiss Federal Research Institute WSL, Zürcherstrasse 111, 8903 Birmensdorf, Switzerland

\begin{abstract}
Dense herbaceous understorey layers can impact tree regeneration and thereby affect forest succession. However, the implications of this interaction on large spatial and temporal scales are not well understood. To analyse the role of overstorey-understorey interactions for forest dynamics, we implemented an understorey layer (composed of the plant functional types grasses, forbs, ferns, herbs and shrubs) in the forest landscape model LandClim, focusing on competition for light as the main mode of interaction. The model was used to simulate post-disturbance dynamics over an elevational gradient of 560-2800 m a.s.l. in Central Europe. Simulation results showed strong impacts of the herbaceous understorey on tree regeneration within the first decades, but generally little effect on late-successional forests, i.e. not providing any evidence for 'arrested' succession. The results also demonstrated varying overstorey-understorey interactions across the landscape: strongest effects
\end{abstract}

Received 22 December 2015; accepted 14 April 2016; published online 8 June 2016

Electronic supplementary material: The online version of this article (doi:10.1007/s10021-016-9999-5) contains supplementary material, which is available to authorized users.

Author Contribution TT., R.S.S. and H.B. designed the study; T.T. and R.S.S. developed the submodel; T.T. conducted the simulation experiments; K.K-P. contributed data; T.T., H.B., K.K-P. and R.S.S. wrote the paper.

*Corresponding author; e-mail: timothy.thrippleton@usys.ethz.ch were found at low to mid elevations of the study landscapes, where tree establishment was substantially delayed. At high elevations, tree growth and establishment were more limited by low temperatures, and the effect of light competition from the understorey was negligible. Although the inclusion of large windthrow disturbances increased the biomass of herbaceous understorey across the landscape, this had only a small impact on the overstorey due to the presence of advance regeneration of trees. Overall, our results demonstrate that the herbaceous understorey can have a significant impact for forest landscape dynamics through light competition, and that non-woody plants should not be neglected in forest modelling.

Key words: herbaceous vegetation; overstoreyunderstorey interaction; arrested succession; Black Forest; Dischma valley; central Alps; dynamic vegetation model.

\section{INTRODUCTION}

Biotic interactions are increasingly recognized as key mechanisms that influence vegetation dynamics at larger scales (for example, Nieto-Lugilde and others 2015). In forests, the study of biotic interactions has mostly focused on competition between woody species (Bugmann 2001; Gilliam 2007) and plant-animal interactions (for example, Kupferschmid and others 2015). The 
interaction between the herbaceous understorey and the woody overstorey is usually considered as a one-way interaction, i.e., overstorey trees determine the composition of understorey herbs by controlling the amount of light reaching the forest floor (Gilliam 2007; Li and others 2012). However, an increasing number of empirical studies have demonstrated that the herbaceous understorey can significantly interfere with tree regeneration and therefore impact the composition and dynamics of the overstorey (George and Bazzaz 1999a; Royo and Carson 2006). Thus, it is important to consider not only the 'top down' effect of trees on the herbaceous layer, but rather a two-way interaction where herbs can also have a 'bottom up' effect on tree population dynamics.

The herbaceous understorey has a range of effects on tree regeneration, but a general understanding of the underlying mechanisms is only beginning to emerge (Balandier and others 2006; Royo and Carson 2006; Li and others 2012). In temperate forests, competition for light is thought to be the most important factor (Nabuurs 1996; George and Bazzaz 2003), although competition for water and/or nutrients may have a strong influence under dry and/or poor soil conditions (Coomes and Grubb 2000).

The magnitude of light competition between the overstorey and the understorey varies over time. Early successional, open sites are typically dominated by light-demanding grasses, forbs and shrubs (Lieffers and others 1993; Ellenberg 1996). As the canopy closes, these are subsequently replaced by more shade-tolerant herbaceous species (Alaback 1984; Hart and Chen 2006). Within the first 15-20 years, the effect of the herbaceous layer on tree regeneration is usually considered to be strongest (Balandier and others 2006). However, extreme cases have been described where the herbaceous layer diminishes tree regeneration to such an extent that the ecosystem becomes 'trapped' in an open herbaceous/shrub stage and does not revert to forest (termed 'arrested succession'; Niering and Goodwin 1974). Other studies have shown that herbaceous vegetation can significantly delay tree regeneration even under closed-canopy conditions (for example, George and Bazzaz 1999a, b). Thus, although it is clear that the effect of the herbaceous layer is not restricted to the first years of succession, its magnitude remains somewhat elusive.

Compared to our knowledge on temporal dynamics, much less is known how overstoreyunderstorey interactions vary across space, i.e., at the landscape scale. The composition and biomass of the understorey may change in response to soil depth, slope and overstorey stand structure (Hart and Chen 2006). As canopy conditions become more open, herbaceous biomass typically increases (Alaback 1984; Ellenberg 1996). This effect becomes particularly evident in mountain forests, where increasingly open forest canopies at higher elevations result in the formation of dense herbaceous layers that can impede tree regeneration (for example, Ott and others 1997; Frehner and others 2005). At the landscape scale, disturbances are central for structuring spatial heterogeneity and driving ecosystem dynamics (Turner and others 2001). Large-scale disturbances such as windthrow and wildfires are of particular importance for the herbaceous layer, since they produce an environment with favourable conditions for pioneer species (Turner and others 1997). The interaction between the herb and the tree layer can therefore be expected to intensify in areas with frequent disturbances, or under scenarios of future conditions that feature an increased disturbance frequency (IPCC 2013).

The restricted spatial and temporal context at which herbaceous understorey effects are usually investigated (McCarthy 2003) poses a severe obstacle to the generalization of overstorey-understorey interactions. Using dynamic forest landscape models, the constraints of long time spans and large spatial extents can be overcome (Bugmann 2001; Mladenoff 2004). In particular, mechanistic (so-called 'process-based') models enable us to explore and disentangle complex ecological interactions (for example, of climate, biotic interactions, disturbances and land-use change).

Despite repeated pleas to include a herbaceous layer in dynamic models of forest growth (for example, Maguire and Forman 1983; Weisberg and others 2003; McKenzie and others 2009), there are only a few process-based forest models that have put this into practice (for example, Kellomäki and Väisänen 1991). Dynamic global vegetation models (DGVMs) generally include herbaceous and shrubby components (for example, LPJ-GUESS, Smith and others 2001; SEIB-DGVM, Sato and others 2007), but their modelling is coarse, geared towards the continental- to global-scale distribution of broad plant categories and the general implications for land surface processes (for example, Hickler and others 2012). To our knowledge, no process-based forest model has been used specifically to investigate the two-way interactions between the overstorey and understorey layers. Here, we introduce a dynamic understorey layer in the forest landscape model LandClim (Schumacher 2004) to investigate how competition for light 
influences overstorey-understorey interactions at large spatial and temporal scales. Specifically, we address the following questions:

(1) To what extent does herbaceous vegetation delay overstorey tree succession? Can intense light competition by the herbaceous understorey result in 'arrested' succession?

(2) How do overstorey-understorey interactions vary over time and across elevational gradients? In particular, do low-elevation forests differ from high-elevation forests?

(3) To what extent does the occurrence of large windthrow disturbances intensify overstoreyunderstorey interactions at the landscape scale?

\section{Material AND Methods}

\section{The Forest Landscape Model}

LandClim is a forest landscape model that simulates competition-driven dynamics in complex topography (Schumacher 2004; Schumacher and others 2004). LandClim has been used to study forest dynamics under past, present and future climate conditions across a range of landscapes in temperate forests in central and southern Europe (Schumacher and others 2004; Henne and others 2013), North America (Schumacher and others 2006) and New Zealand (Thrippleton and others 2014). Landscapes are represented in LandClim in the form of raster grids $\left(25 \times 25 \mathrm{~m}^{2}\right)$ with specific environmental conditions for each grid cell (i.e., aspect, slope, soil and climate). Within each grid cell, stand-scale processes are simulated, that is the establishment, growth and mortality of tree cohorts (groups of even-aged trees of the same species). Intra- and inter-specific competition for light and soil water is taken into account. LandClim also incorporates landscape-scale processes such as seed dispersal, windthrow, fire and bark beetle dynamics.

Light extinction through the canopy is modelled using the Lambert-Beer Law (Bugmann 2001; Monsi and Saeki 2005). Light limitation reduces tree growth and influences the probability of regeneration as well as the density and biomass of new tree cohorts. The fate of young tree cohorts is tracked over ten years before these trees are considered as successfully established. During this time, the number of years with suitable conditions for establishment (for example, light availability above a species-specific threshold) and actual tree growth performance determine establishment probability. The density of actually established trees is influenced by light availability at the forest floor (see Schumacher and others 2004). Thus, unfavourable light conditions (such as due to herbaceous competition) can stop tree regeneration and theoretically halt succession. A more detailed description of LandClim can be found in Schumacher (2004).

\section{Representation of Herbaceous Understorey}

Due to the high species diversity in the understorey, we chose to represent it as plant functional types (PFTs), i.e., species groups based on similar architecture and ecological strategies (for example, Weisberg and Bugmann 2003; Balandier and others 2006). We focus on four groups of herbaceous PFTs (listed according to increasing shade tolerance, compare online Appendix Al): grasses, tall forbs, ferns and small herbs. A shrub PFT was also included to represent Rubus spp., for comparison with the empirical data by Priewasser (2013) (compare section 'Model evaluation' and online Appendix Al). Details on the parameterization of the understorey PFTs are provided in online Appendix Al.

Each understorey PFT is represented in LandClim as a single cohort per grid cell. Because LandClim has an annual time step and does not consider growth dynamics within the growing season, understorey PFTs can be assumed to be present all the time, i.e. from the point of view of the model that they are perennial, even though from a botanical point of view that they may of course be annual plants. Their annual growth rate was modelled using a logistic growth equation, similar to the one used for tree growth (Schumacher and others 2004). In contrast to trees, however, negative growth is possible for herbaceous PFTs. Herbaceous cohorts can therefore lose biomass from one year to the next if environmental conditions (light, water, temperature) are deteriorating.

The herbaceous understorey casts shade on the forest floor in addition to the shading exerted by the tree layers. Light extinction by herbs is calculated analogously as for trees, using the LambertBeer Law (Monsi and Saeki 2005), which is a function of leaf area index (LAI) and a light extinction coefficient (0.6; Pitman 2000). The LAI of each herbaceous PFT was calculated in two steps for each grid cell. First, LAI for each herbaceous cohort was calculated from cohort biomass using an allometric function (equation 1) that was derived by fitting a linear model to empirical data (compare 
online Appendix A3). Second, herbaceous vegetation cover $\left(\right.$ cover $\left._{\text {Herb }}\right)$ was considered as an additional, down-weighting factor in the calculation of the grid cell LAI for each cohort (equation 2), to account for the patchiness of the herbaceous vegetation at scales of a few metres (George and Bazzaz 2003). The percentage of ground cover by each PFT was calculated using allometric equations from different empirical studies (compare online Appendix A4).

$$
\begin{gathered}
\text { LAI }_{\text {Herb }}=0.7442 \cdot \text { Biomass }_{\text {Herb }} \\
\text { LAI }_{\text {Herb,cohort }}=\mathrm{LAI}_{\mathrm{Herb}} \cdot \text { cover }_{\mathrm{Herb}}
\end{gathered}
$$

\section{Sensitivity Analysis for Herbaceous Growth Parameters}

The herbaceous growth parameters (maximum growth rate ' $\mathrm{R}_{\max }$ ' and maximum biomass ' $\mathrm{K}_{\max }$ ') are decisive for determining the outcome of competition with trees, but their values are subject to considerable uncertainty (compare online Appendix 1). Thus, these parameters were studied in more detail using a sensitivity analysis. Parameters were varied within ranges informed by empirical measurements (compare online Appendix A3). Maximum biomass was varied from 16 to $800 \mathrm{~g} \mathrm{~m}^{-2}$ (i.e., $\left.0.16-8 \mathrm{t} \mathrm{ha}^{-1}\right)$, and maximum growth rate varied from 0.01 to $1 \mathrm{y}^{-1}$ (equivalent to $>50$ and $<10$ years to reach maximum biomass, respectively). For the sensitivity analysis, a Latin Hypercube sampling design was used to create 2500 parameter combinations. Simulations were performed with all four herbaceous PFTs (grass, forb, fern, herb) in competition with 16 tree species for 400 simulation years. We used a representative subset of the study landscape in the Black Forest (elevation bands 600, 1000 and $1400 \mathrm{~m}$ a.s.l.; see next section).

\section{Case Study Landscapes}

We applied the model to two case study landscapes, the St. Wilhelm valley $\left(47^{\circ} 52^{\prime} \mathrm{N}, 7^{\circ} 58^{\prime} \mathrm{E}\right.$; total area 1218 ha) on the slopes of Mt. Feldberg in the Black Forest, Germany (referred to as 'Feldberg landscape' below), and the Dischma valley $\left(46^{\circ} 47^{\prime} \mathrm{N}, 9^{\circ} 5 \mathrm{l}^{\prime} \mathrm{E}\right.$; total area $\left.1700 \mathrm{ha}\right)$ in the central Alps near Davos, Switzerland. Both landscapes have a high annual precipitation sum of greater than $1000 \mathrm{~mm}$ (Bogenrieder and Rasbach 1982; Schumacher and others 2004) and were selected because together they represent a large elevation range from $560 \mathrm{~m}$ to above $2800 \mathrm{~m}$ a.s.l. The landscapes are characterized by mesic forests. Light and temperature are the main limiting factors, whereas water limitation plays a minor role only. Climate data and lapse rates for temperature and precipitation for the Feldberg landscape were generated from weather stations in Freiburg i.Br. (236 $\mathrm{m}$ a.s.l.) and at the top of Mt. Feldberg (1490 m a.s.l.) from 1949 to 2012 (DWD, Deutscher Wetterdienst; https://werdis.dwd.de/, July 2014). Details on the topographic and soil input maps for Feldberg are given in online Appendix A2. Information regarding the climate and soil data for the Dischma landscape can be found in Schumacher and others (2004).

\section{Simulation Experiments}

For analysing the spatio-temporal patterns at the landscape scale, LandClim was run for 400 years of forest succession for the Feldberg and Dischma landscapes. This is equivalent to the time scale of the chronosequence by Jules and others (2008), which was used for model evaluation (see below). Growth parameters for the herbaceous species were based on empirical studies of post-windthrow vegetation dynamics in the Black Forest (Sayer and Reif 1999) (compare online Appendix Al). To evaluate the effect of understorey vegetation on forest succession, simulations were run for both landscapes in two scenarios: (1) only trees and (2) trees and understorey vegetation. All scenarios were simulated with 10 iterations to account for stochastic variability in the model. For each model iteration, the climate records for the landscapes of Mt. Feldberg and Davos were re-sampled with replacement, so as to generate a 400 -year climate sequence representing present-day climate.

To analyse the impact of windthrow disturbances, three scenarios were compared: (1) control, no disturbances; (2) windthrow disturbances with a 600 -year rotation period and (3) windthrow disturbances with a rotation period of 400 years (representing 'intermediate' and 'strong' windthrow disturbance scenarios, see Schumacher 2004). Average and maximum windthrow sizes were based on windthrow reports from the Black Forest by Fischer (1999) (average $=2$ ha, maximum $=73.8$ ha). Windthrow simulations were performed for the Feldberg landscape only, as this disturbance type plays a minor role in the Dischma landscape.

\section{Model Evaluation}

The simulated temporal patterns of overstoreyunderstorey development were compared to a 420year chronosequence by Jules and others (2008) 
that used forest sites of different ages under otherwise similar abiotic conditions to study successional dynamics. Chronosequences are appropriate for describing the aggregated characteristics of plant communities (Walker and others 2010) and can provide qualitative information on the long-term interaction between tree overstorey and herbaceous understorey.

Three stages of herbaceous succession are evident from the study of Jules and others (2008): stage 1-an understorey peak (mostly grasses and shrubs) within the first 25 years; stage 2-a gradual decline towards a minimum cover around year 80100 and stage 3-an increase in herb cover thereafter. Since other long-term studies described similar qualitative patterns (Oliver 1981; Alaback 1982; Alaback 1984), we considered these three stages as robust results for the model evaluation, despite potential complications from land-use history.

The ecological differences between the study region of Jules and others (2008) and the Black Forest landscape, however, restricted the comparison to a qualitative evaluation of broad trends in tree and understorey succession.

Simulated spatial patterns were compared to vegetation data from herbaceous species on 90 post-windthrow plots across the Northern Swiss Alps by Priewasser (2013), which covered an elevation range from 370 to $1800 \mathrm{~m}$ a.s.l. Vegetation data had been collected in 2011 on windthrow sites affected by the storm Vivian (1990) and Lothar (1999), thus providing a detailed and highly accurate picture of herbaceous vegetation composition approximately 10 and 20 years after disturbance (for details compare Priewasser 2013; Kramer and others 2014). Trends in elevational distribution of dominant herbaceous vegetation were similar at both storm sites, and were therefore combined for an evaluation of the model (Figure 3I). To ensure that elevational trends are due to climatic constraints and not confounded by varying $\mathrm{pH}$ and overstorey vegetation, only data from acidic sites within former spruce forests were included.

Analyses of all model outputs were performed in the statistical software $R$, version 3.1.2 (R Development Core Team 2014).

\section{RESUlTS}

\section{Sensitivity Analysis}

The sensitivity analysis showed consistent patterns for all herbaceous PFTs over time (Figure 1). Understorey effects on forest biomass were strongest in the first 100 years of succession, but they practically disappeared by the year 400 . The parameter $R_{\max }$ (maximum growth rate) influenced the results only when it was greater than $0.2 \mathrm{y}^{-1}$, whereas the parameter $K_{\max }$ (maximum biomass) had a strong effect throughout the investigated parameter range. Very high $K_{\max }$ values resulted in a strong delay of tree biomass development up to the year 100, particularly for the more shade-tolerant PFTs (i.e., ferns and herbs; Figure 1C, D).

\section{Landscape Simulations: Temporal Patterns}

The understorey PFTs showed a peak at the beginning of succession, which decreased to a rather low level after 20-30 years at low elevations (Feldberg, $600 \mathrm{~m}$ a.s.l.; Figure 2C) and after 40-50 years at high elevations (Dischma $1800 \mathrm{~m}$ a.s.l.; Figure 2D). This difference was caused by much faster tree succession at low elevations (Feldberg $600 \mathrm{~m}$; Figure 2A, B).

At low elevations, the three broad stages of understorey succession were visible in the simulation results: a pronounced peak of understorey vegetation (mainly grass, ferns and Rubus), followed by a biomass drop in the first century and the occasional re-occurrence of the pioneer PFT Rubus after around year 150 (Figure 2C).

\section{Landscape Simulations: Spatial Patterns}

Understorey vegetation followed clear elevational trends in both landscapes (Figure 3). Elevations below $1000 \mathrm{~m}$ were dominated by Rubus, fern and grass in the first 20 simulation years (Figure 3A, C). At elevations from 1100 to $2000 \mathrm{~m}$, grass became increasingly important in terms of relative biomass. Herbs and forbs were consistently present at low biomass across the elevation gradient. Notably, elevational patterns shifted over time. Whereas elevations below $1000 \mathrm{~m}$ were strongly affected by shading from canopy trees already at years 20 and 30, mid and high elevations still had higher levels of herbaceous biomass (Figure 3C, E). This herbaceous peak shifted upwards with the progression of succession (Figure 3E-H). Empirical data from Priewasser (2013) about vegetation composition at years 10-20 showed a dominance of Rubus and fern at lower elevations and forbs and grasses at higher elevations (Figure 3I).

\section{Understorey Impact on Forest Dynamics}

At low elevations, the presence of understorey vegetation delayed forest succession by several 

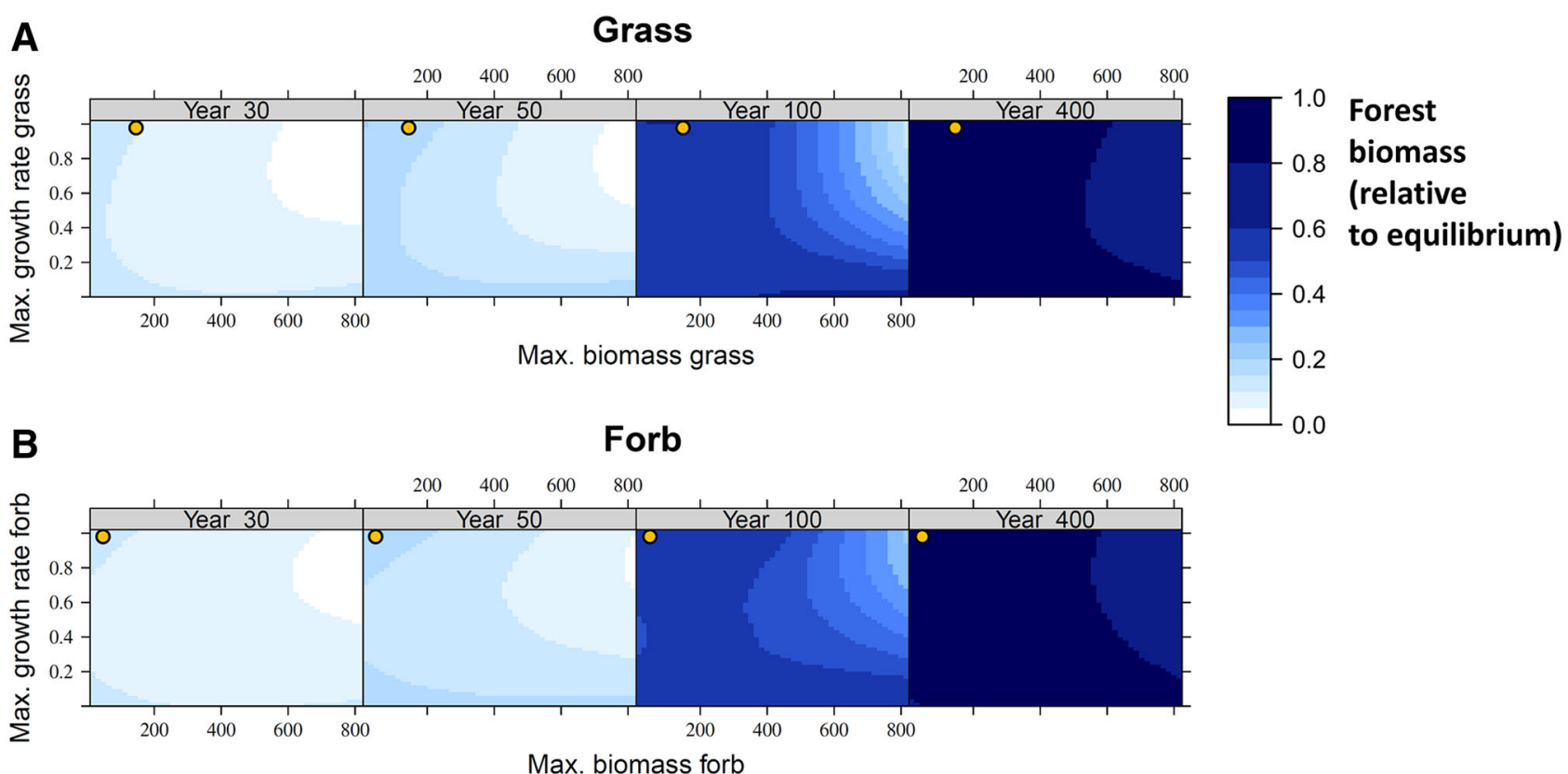

Max. biomass forb

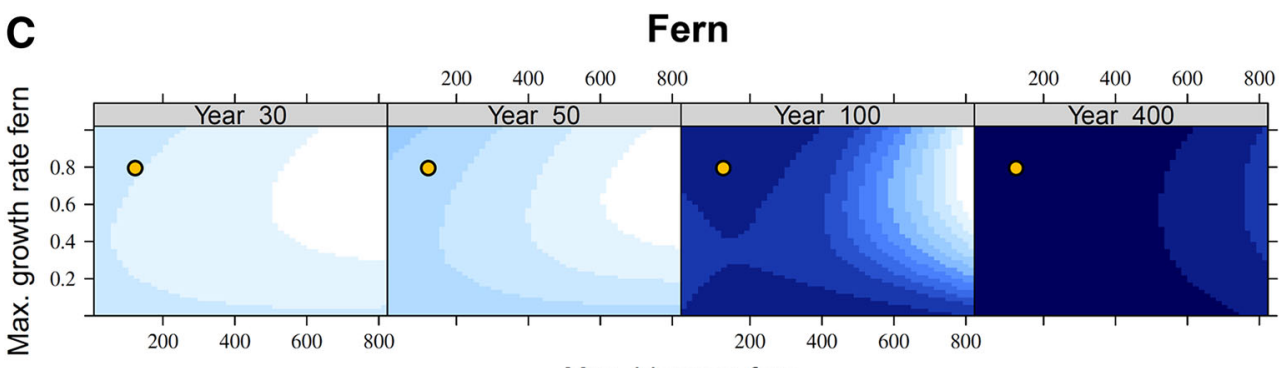

Max. biomass fern

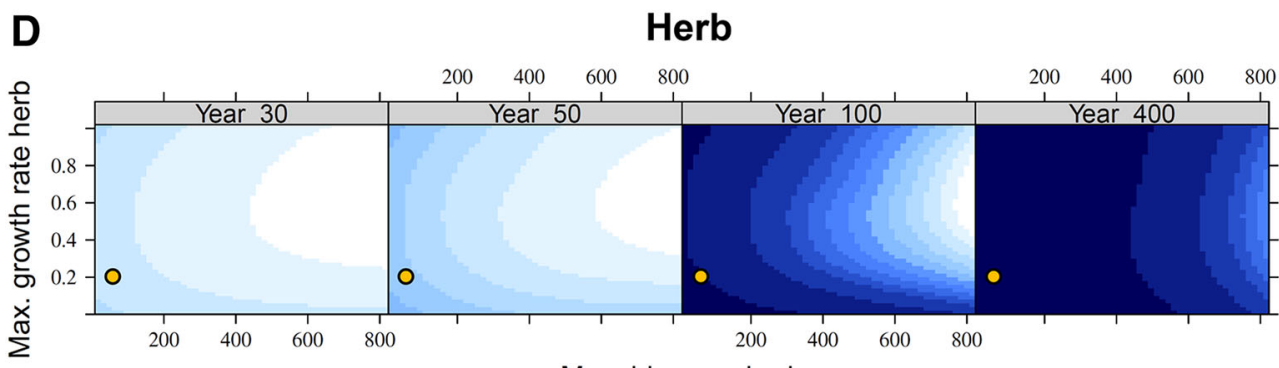

Max. biomass herb

\section{No Understorey}

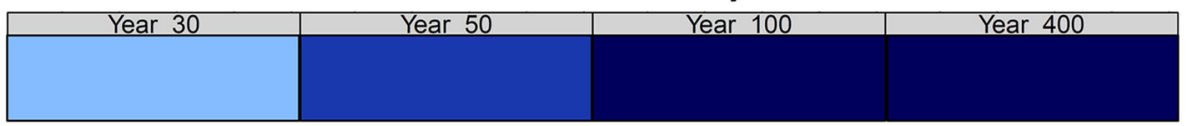

Fig. 1. Sensitivity analysis of the herbaceous growth parameters 'maximum biomass' $\left(\mathrm{g} \mathrm{m}^{-2}\right)$ and 'maximum growth

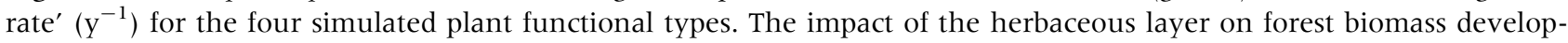
ment (expressed as biomass relative to equilibrium biomass, that is, $400 \mathrm{t} / \mathrm{ha}$ ) is shown. Orange points mark the parameters of each PFT used in the following landscape simulations (see also Table Al.1). The 'No Understorey' results show the forest biomass growth of a single scenario in the absence of herbaceous understorey (thus no parameters were varied here) (Color figure online) 

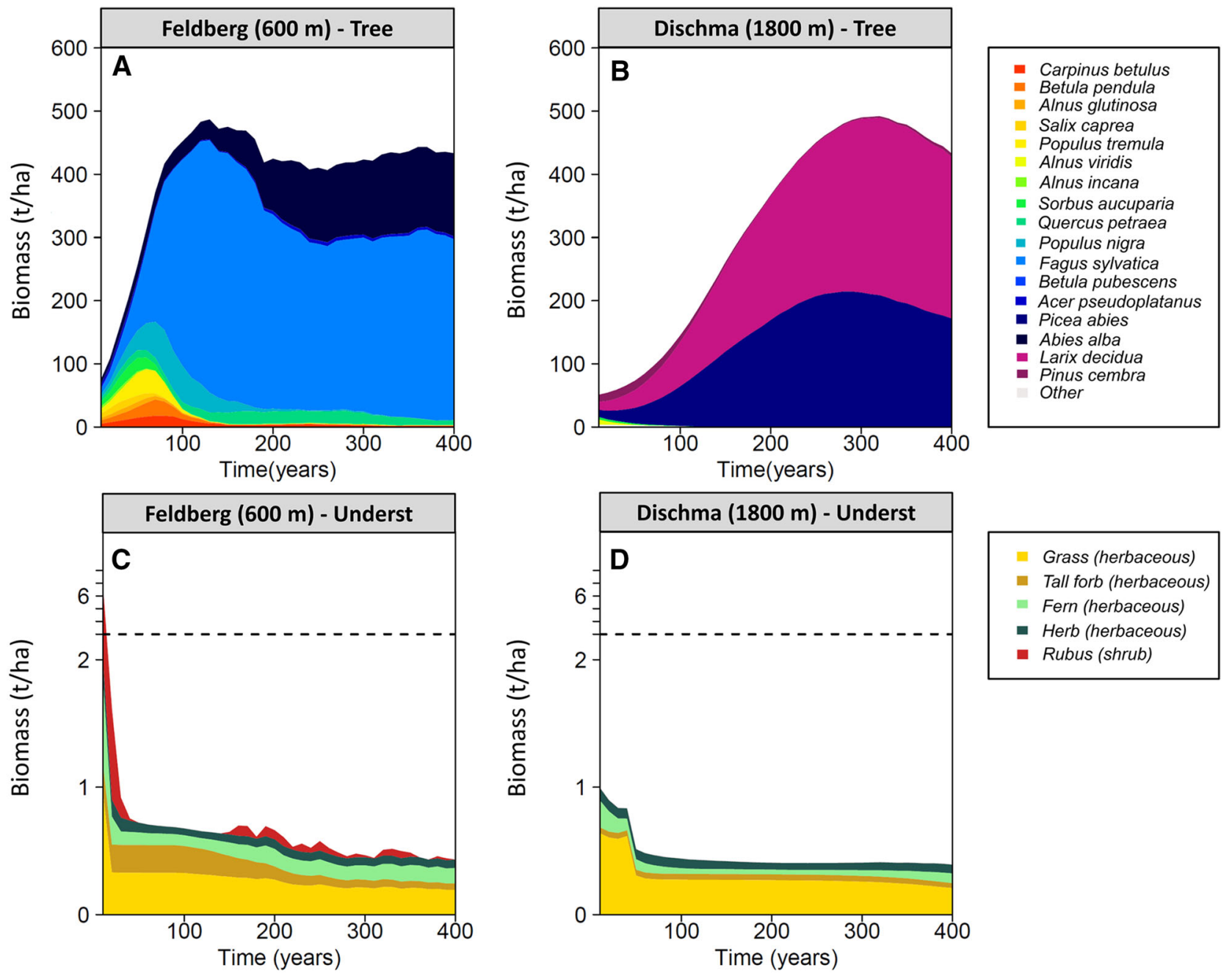

Fig. 2. Succession of tree species and understorey in the study landscapes (A, C) Feldberg at $600 \mathrm{~m}$ a.s.l. and (B, D) Dischma at $1800 \mathrm{~m}$ a.s.l. For clarity, the $y$-axis was rescaled by a factor of 10 above the horizontal dashed line

years and decreased initial tree biomass by $32 \%$ (Figure 4A, C). With increasing elevation, the difference in total tree biomass between scenarios with or without understorey diminished (Figure 4B, D) and became negligible at elevations above $1900 \mathrm{~m}$ (Figure 4E-H). Across all elevations, the understorey effect diminished after a few decades, and simulated biomass was virtually the same after approximately 70 years (Figure 4C, D). Correspondingly, within the first decade available light at the forest floor was reduced by the introduction of herbaceous vegetation by $30 \%$ at Feldberg (600 m a.s.l.) and $8 \%$ at Dischma (1800 m a.s.l.), but became negligible at both landscapes by the year 400 (results not shown). Despite the decreasing impact on total tree biomass with time, the introduction of herbaceous vegetation did induce a long-lasting shift in dominant tree species throughout the landscape (Figure 5). This was particularly apparent for low and mid elevations in the Feldberg landscape (Figure 5A, B), where lightdemanding species such as Betula and Salix were replaced by more shade-tolerant species (mostly Fagus sylvatica). The effect of the understorey on tree species dominance was less pronounced in the Dischma landscape (Figure 5C, D), although there was a discernible decrease of Larix decidua in favour of Picea abies. Differences in terms of dominant tree species distribution were still evident up to the simulation year 200 (compare online Appendix A5).

\section{Effects of Windthrow}

The occurrence of large windthrow disturbances strongly increased average herbaceous biomass across the landscape (up to 56\%; Figure 6). 

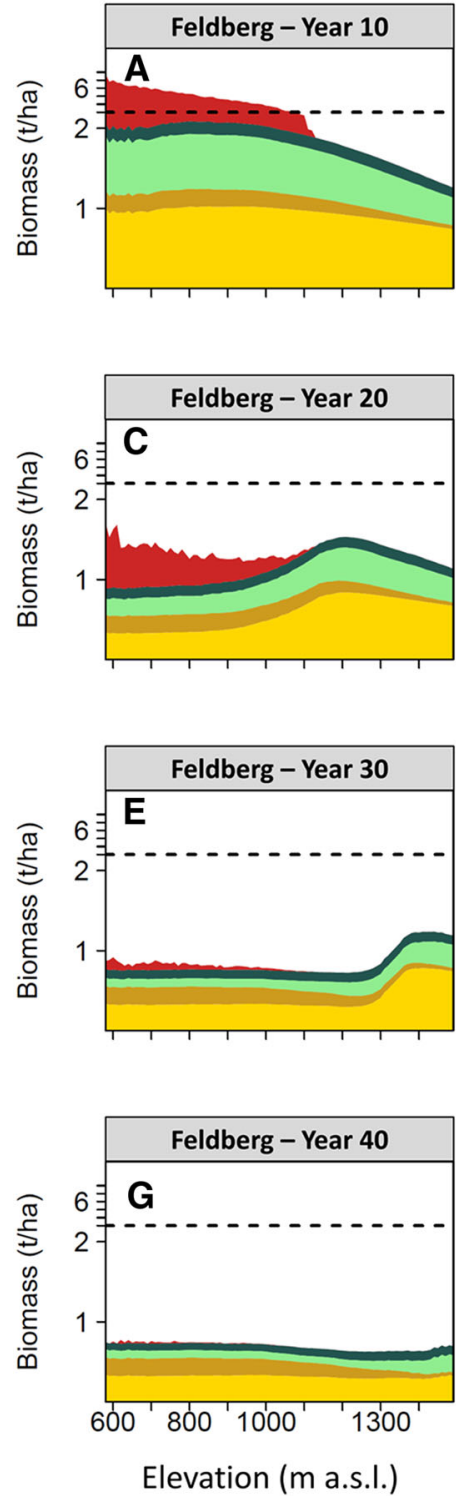

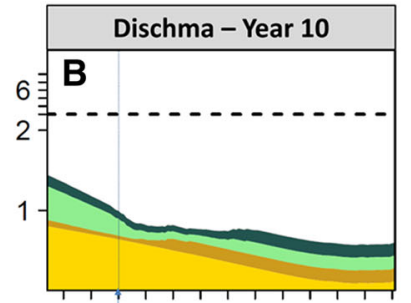

Upper elevation limit of empirical data
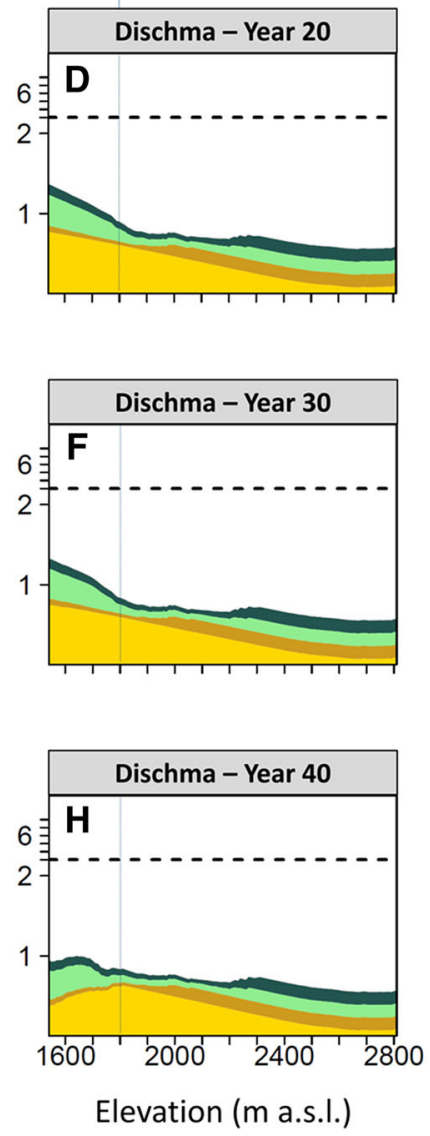
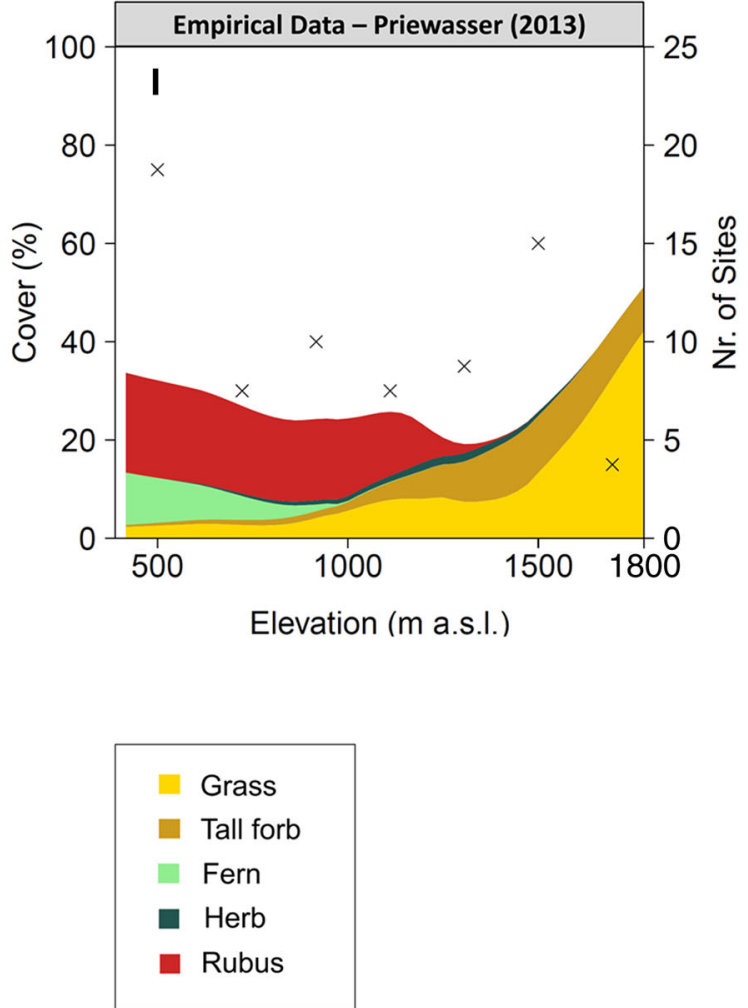

Fig. 3. Distribution of understorey plant functional types along an elevation gradient for Feldberg and Dischma. For clarity, the $y$-axis was rescaled by a factor of 10 above the horizontal dashed line. Cross marks in panel I show the number of study sites within each 200-m elevation belt. Sites shown in panel I represent the composition of herbaceous vegetation at an age of approximately 10-20 years

Windthrow disturbances also reduced mean tree biomass across the landscape. Including herbaceous understorey in the simulations slightly enhanced the understorey effect on the tree overstorey, although it was relatively small (Figure 6, difference between 'tree biomass-no herb layer' and 'tree biomass-with herb layer').

\section{Discussion}

The understorey layer as implemented in LandClim produced simulation results that were not only realistic and plausible, but also consistent with the broad patterns evident from empirical data. Below, we discuss in more detail (1) the effects of herbaceous understorey on delaying forest succession (with particular consideration of 'arrested' succession), (2) emerging spatio-temporal patterns (comparing low-elevation with high-elevation forests) and (3) the importance of disturbance events for overstorey-understorey interactions. Notably, the simulation results consider light competition as the predominant interference mechanism between trees and herbs (as 

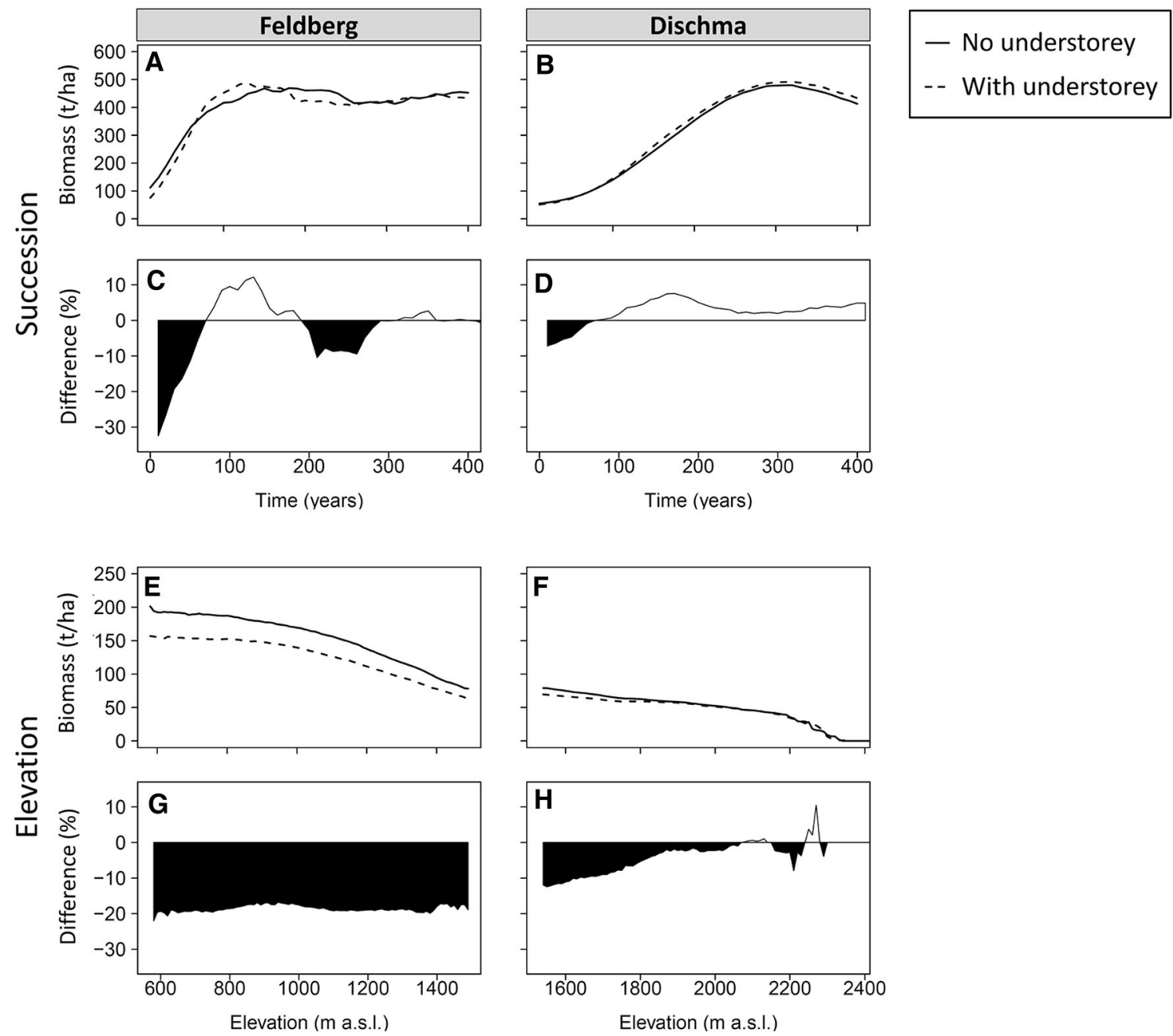

Fig. 4. Effect of understorey vegetation on forest biomass development with time (A-D) for Feldberg at $600 \mathrm{~m}$ and Dischma at $1800 \mathrm{~m}$, and across the elevational gradient at year $30(\mathbf{E}-\mathbf{H})$. In both cases, the top panels $(\mathbf{A}, \mathbf{B}, \mathbf{E}, \mathbf{F})$ illustrate the absolute biomass values and the bottom panels $(\mathbf{C}, \mathbf{D}, \mathbf{G}, \mathbf{H})$ show the percent difference between the two lines (with and without understorey)

suggested by Horsley 1993; DenOuden 2000; George and Bazzaz 2003).

\section{Can Light Competition with Herbaceous Understorey Arrest Forest Succession?}

In the sensitivity analysis, we studied the effect of the herbaceous understorey on delaying forest succession and tested whether the case of 'arrested succession' occurs. We showed that the model simulates significantly delayed forest succession when herbaceous vegetation has high maximum biomass (Figure 1), so that even after 100 years practically no forest had established. This finding is consistent with studies from DenOuden (2000) and Koop and Hilgen (1987), who described a stagnation of forest succession for several decades due to interactions between the herbaceous understorey and tree regeneration. However, as shown by George and Bazzaz (1999a, b), a small fraction of trees are able to survive phases of strong herbaceous competition and become established. Therefore, after several decades some trees eventually emerge above the herbaceous canopy and progressively shade out understorey vegetation (for example, Lieffers and others 1993). In a similar manner, the herbaceous understorey greatly reduced the success of tree establishment in our simulations, but ultimately could not stop reforestation in the long term (400 years). Our results thus suggest that even though an ecosystem may appear to be in a state of 'arrested' succession, this may simply be a matter of perspective and the relatively short lifespan of humans (and their lack 

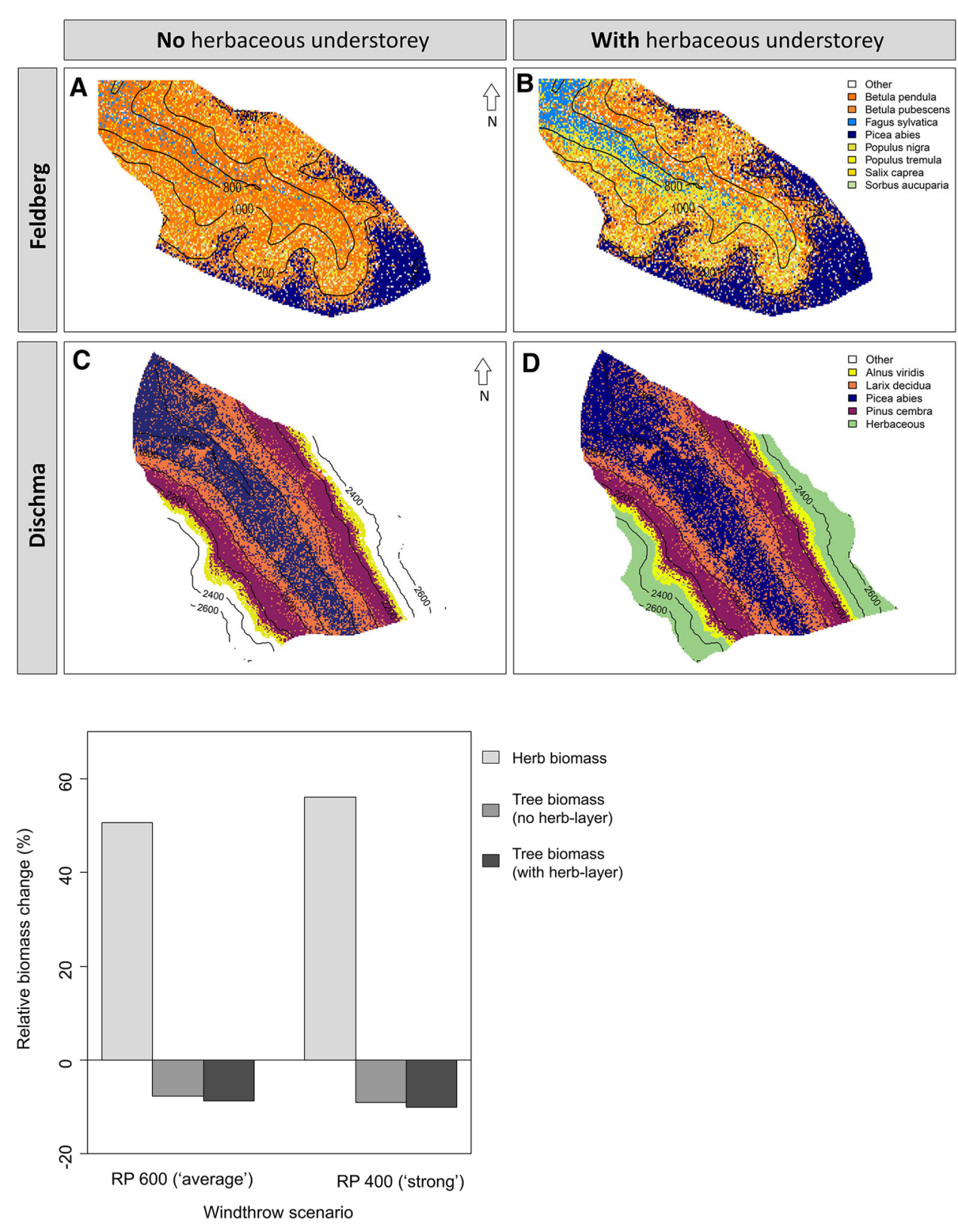

Fig. 5. Maps of dominant species for the Feldberg and Dischma landscapes at year 50 of the succession, excluding and including understorey vegetation of patience) compared to forests (compare Hiltbrunner and others 2014).

There are, however, several ecological processes that are not considered in the model that may influence the interaction between trees and understorey. They include (1) competition for water and nutrients (for example, Provendier and Balandier 2008), although forests in the mesic landscapes studied here are unlikely to be strongly constrained by these factors (Bogenrieder and Rasbach 1982; Schumacher and others 2004); (2) enhanced seed predation, but little quantitative knowledge is available on this (Royo and Carson 2008); (3) allelopathic effects (for example, Nilsson and Wardle 2005), which are hard to study experimentally (Priewasser 2013); (4) mechanical inhibition of seedling germination and growth (for example, Dolling 1996) and (5) interactions with browsing animals (for example, Stromayer and Warren 1997).

The interference of browsing deer and herbaceous understorey is considered to be particularly important for 'arrested' succession (Stromayer and Warren 1997; Royo and Carson 2006). Continuous browsing pressure results in the suppression of tree establishment and a depauperation of the herbaceous understorey (Royo and Carson 2006). Only few unpalatable herbaceous species remain unaf- 
fected by browsing and can subsequently form a dense understorey (for example, the ferns Dennstaedtia punctilobula and Pteridium aquilinum; de la Cretaz and Kelty 1999; DenOuden 2000). It remains unclear, however, how persistent those dense understorey layers are in the long term and in the absence of additional disturbance processes (Royo and Carson 2006). There is some empirical evidence showing that after reduction of deer browsing, trees gradually re-established despite competition with a dense herbaceous understorey (de la Cretaz and Kelty 2002). Thus, even though light competition can substantially reduce tree regeneration it appears unlikely that this mechanism alone could result in arrested succession.

\section{Emerging Temporal and Spatial Patterns of Overstorey-Understorey Interactions}

Early successional dynamics were affected most strongly by the presence of herbaceous understorey vegetation. Using the herbaceous growth parameters derived from the Black Forest dataset, the model produced an understorey biomass (herbaceous and Rubus PFTs) comparable to measurements from temperate and boreal regions (for example, 5.2 t/ha, Alaback 1982; 6.9 t/ha, Lieffers and others 1993; 1.5-5.7 t/ha for Rubus, Kowalenko 2003). In the model, the simulated understorey biomass resulted in a 30\% reduction of light availability at the forest floor, which is a realistic but somewhat low estimate (compared to empirical data, which measured light reductions of $30-85 \%$; Shropshire and others 2001). The simulated delay of forest succession by 10 years at lower elevations of the Feldberg landscape matches empirical data well, reporting delays of 10-20 years (Balandier and others 2006). Some studies found longer-lasting delays (for example 20-30 years in boreal forests, Lieffers and others 1993; Royo and Carson 2006), which could be simulated with a relatively minor increase in the $K_{\max }$ ('maximum biomass') parameter of the herbaceous PFTs (see Figure 1). Overall, the model produced simulation results that were in agreement with empirical patterns of early successional dynamics.

Long-term successional patterns of herbaceous understorey are often described in three broad stages (for example, Alaback 1982; Alaback 1984; Jules and others 2008): (1) an initial biomass peak, followed by (2) a phase of low biomass and (3) understorey re-initiation. These patterns emphasize the importance of the overstorey canopy for controlling understorey growth trends (Lieffers and others 1993; Hart and Chen 2006). LandClim sim- ulated the first two phases in good accordance with empirical observations, that is, the initial peak and decrease of understorey biomass associated with the development of the overstorey. However, understorey re-initiation occurred only weakly in the simulation results (that is, the re-appearance of pioneer PFT Rubus at year 200, Figure 2C). This was mostly due to the aggregation of the results to the landscape level. Individual grid cells in LandClim may differ strongly from each other in terms of environmental conditions and stochastic processes (for example, establishment, mortality), more so later in the simulation than at the beginning, thus resulting in different forest structures at any one time and a strong dilution of the visibility of understorey re-initiation (compare online Appendix 6). The first two phases were detected clearly because the simulation was started from bare ground, leading to the synchronous development of these stages across the entire landscape. Thus, the simulated long-term successional trends of the herbaceous understorey are consistent with empirical studies, although the distinctness of latesuccessional patterns may depend on the level of spatial aggregation of the data.

The most prominent spatial pattern across the simulated landscape was the change in species abundance with elevation due to temperature limitation.

The empirical data from Priewasser (2013) showed a similar elevational pattern for Rubus, whereas ferns and forbs were more evenly distributed in the simulation results than in the data. At high elevations (>1200 $\mathrm{m}$ a.s.l.), grass increased in relative importance in the model as well as in the empirical data, although it must be noted that only three study sites were located at elevations $>1600 \mathrm{~m}$ (see Figure 3I). In the model, the elevational distribution of the species is driven largely by the parameter minDD ('minimum degree-day sum'), which was derived from literature and based on a broad set of herbaceous species (for example, Laurent and others 2004, see online Appendix Al). Generally, our parameter estimates reflect the maximum climatic niches of the PFT groups, thus the actual climatic niches of the species that are present in our study landscapes may have been narrower.

Across the simulated elevation gradient, decreasing temperature strongly influenced overstorey-understorey interactions. On the one hand, low temperature led to a prolonged initial peak of herbaceous biomass at higher elevations due to the slower growth of the overstorey. On the other hand, cold conditions also resulted in a substantial 
decrease of herbaceous biomass. It was this latter effect that was predominant in the model, thus leading to a smaller impact of the herbaceous layer on tree regeneration in the high-elevation Dischma landscape compared to the Feldberg landscape. Relatively few empirical studies exist that have examined overstorey-understorey interactions across elevations.

At the upper treeline, herbaceous vegetation had either neutral or even slightly positive effects on conifer seedling survivorship (Maher and others 2005). Yet, Kupferschmid and Bugmann (2005) found that spruce establishment was limited by strong competition with ferns and particularly Calamagrostis grasses in the higher subalpine sites compared to montane forests. Weisberg and others (2003) showed that in patches of higher light availability at subalpine sites, Calamagrostis and other graminoid species strongly increased in ground cover and outcompeted other PFTs. Notably, Calamagrostis competes not only for light, but can also form impermeable mats due to the accumulation of dead biomass over several years, which hinders conifer regeneration (mostly Picea abies) particularly at high elevations (Ott and others 1997). Confounding interference mechanisms such as this one make it challenging to evaluate the elevational patterns of light competition directly. As the production of aboveground biomass in herbaceous plants is positively correlated with temperature (for example, Raich and others 1997; De Long and others 2015), a reduction of herbaceous biomass and thus light competition at higher elevations, as simulated by the model, is consistent with broad empirical patterns.

Individual tree species had different responses to the herbaceous understorey, depending on their shade tolerance. The strongest shift in tree species dominance occurred at low elevations, where shade-tolerant species (mostly Fagus sylvatica) were favoured at the expense of light-demanding species (for example, Betula, Salix). A number of studies report similar findings (for example, Koop and Hilgen 1987; George and Bazzaz 1999a), where establishment of light-demanding species, in particular Betula, was drastically reduced by the presence of a herbaceous understorey, whereas more shade-tolerant species (for example Acer, Picea, Fagus) were less affected. The simulation results further emphasize the long-term effect (up to 200 years) of the relatively short peak of herbaceous understorey during the first 10-20 years. Considering the entire range of spatial and temporal scales simulated, the impact of understorey competition on tree regeneration was found to be strongest during early succession and at lower elevations. However, the model also demonstrated that understorey competition can have a much longerlasting impact on tree species composition.

\section{Importance of Disturbance Events}

Disturbances (of both human and natural origin) have been suggested to alter the strength of overstorey-understorey interactions (Royo and Carson 2006). In the simulations, large windthrow disturbances strongly favoured the herbaceous layer locally, and this increase in herbaceous biomass was visible even at the landscape scale. This effect is in accordance with the literature, demonstrating the strong impact of disturbance size on the understorey response (George and Bazzaz 2003). Large disturbances generally lead to a proliferation of herbaceous species, in particular those with a pioneer strategy (Alaback 1984; Hart and Chen 2006). The quick exploitation of resources available after a disturbance by herbaceous vegetation may have consequences for tree succession. For example, large disturbances due to forest fires in Yellowstone National Park resulted in abundant herbaceous vegetation that precluded tree establishment for several decades (Turner and others 1997). After large-scale disturbances, surviving vegetation as well as the availability and dispersal of seeds from nearby sources can play a major role in controlling the rate of forest development (Turner and others 1997; Dale and others 2005). For determining light competition between trees and herbs, the presence of advance regeneration (i.e., juvenile trees) is of particular importance since it can substantially accelerate forest regeneration (George and Bazzaz 2003; Schwitter and others 2015). Simulated windthrows in LandClim affect only larger-sized trees (Schumacher 2004); thus, younger cohorts survive the disturbance event and rapidly shade out the herbaceous layer. The consistent presence of advance regeneration in our simulations was the main reason why the herbaceous layer had a rather small impact on tree biomass in both windthrow scenarios.

Large-scale, 'stand replacing' disturbances where vegetation is entirely removed would most likely have produced a much stronger effect on both the understorey and the overstorey, but they were not simulated here because they are not important in the two case study landscapes. Wildfires in particular have been shown to result in the proliferation of understorey vegetation (Hart and Chen 2006), and a dense herbaceous cover can furthermore lead to positive feedbacks on fire spread across the 
landscape (Allen 2007). Timber harvest can also produce prolonged understorey responses and is replacing wildfire as the most important disturbance type in boreal forests (Hart and Chen 2006).

Even more than a single disturbance type, the co-occurrence of different disturbances (for example windthrow, harvest, fire, browsing) has been highlighted as a key mechanism in the formation of dense understorey layers (Royo and Carson 2006). Although the empirical study of the effects of multiple interacting disturbances is highly challenging (for example, Allen 2007), forest landscape models provide a particularly helpful tool to explore the implications of cross-scale interactions between disturbance regimes (Temperli and others 2013). With the inclusion of herbaceous vegetation as described here, LandClim offers a consistent framework to study the consequences of multiple interacting disturbances on overstorey-understorey dynamics.

\section{ConClusion}

Including herbaceous PFTs in a dynamic forest landscape model allowed us to study the interactive effects of light competition between trees and herbs. We found that forest succession can be significantly delayed by the herbaceous understorey, although there was no evidence for 'arrested' succession in the long term. Our results suggest that the strongest impact of understorey on the development of total forest biomass will be found at lower elevations and during early succession.

Furthermore, light competition with herbaceous plants favours more shade-tolerant tree species, and this shift in species composition was discernible for up to 200 years. The occurrence of large-scale disturbances (here, windthrow) increased herbaceous biomass across the landscape, but did not enhance the understorey effect on tree regeneration as strongly as we expected, due to the consistent presence of advance tree regeneration in the simulations.

Overall, the simulation results emphasize the importance of considering the herbaceous layer when modelling forest dynamics, particularly with respect to understanding (1) the spatial and temporal patterns of early succession and (2) the impacts of large-scale disturbances.

Recognizing that the herbaceous understorey can alter tree species composition and understanding the mechanisms that cause this shift may be especially important for forest management and biodiversity conservation. However, additional ecological processes that are exerted or at least influenced by the understorey layer (for example, competition for water, mechanical inhibition) may be pivotal for the dynamics of some forest ecosystems, but are not included in LandClim yet. Integrating these would allow the model to be applied in ecosystems where factors other than light competition (co-)limit tree regeneration. A better understanding of the factors that influence tree regeneration across temporal and spatial scales will improve our ability to predict tree responses to changes in the environment or management regimes.

\section{ACKNOWLEDGEMENTS}

We gratefully acknowledge the support by Dominic Michel in all IT-related questions, as well as Laura Schuler and Nica Huber for helpful comments on the discussion section. Furthermore, two anonymous reviewers are gratefully acknowledged for providing helpful comments on an earlier version of the manuscript. Funding for R.S.S. was provided by the EU FP7 project "IMPRESSIONS", Grant No. 603416.

\section{REFERENCES}

Alaback PB. 1982. Dynamics of understory biomass in Sitka spruce-western hemlock forests of southeast Alaska. Ecology 63:1932-48.

Alaback PB. 1984. Plant succession following logging in the Sitka spruce-western hemlock forests of southeast Alaska: implications for management. USDA Forest Service General Technical Report. Oregon State University.

Allen CD. 2007. Interactions across spatial scales among forest dieback, fire, and erosion in northern New Mexico landscapes. Ecosystems 10:797-808.

Balandier P, Collet C, Miller JH, Reynolds PE, Zedaker SM. 2006. Designing forest vegetation management strategies based on the mechanisms and dynamics of crop tree competition by neighbouring vegetation. Forestry 79:3-27.

Bogenrieder A, Rasbach H. 1982. Der Feldberg im Schwarzwald: subalpine Insel im Mittelgebirge. Karlsruhe: Landesanstalt für Umweltschutz Baden-Württemberg; Institut für Oekologie und Naturschutz.

Bugmann H. 2001. A review of forest gap models. Clim Change 51:259-305.

Coomes DA, Grubb PJ. 2000. Impacts of root competition in forests and woodlands: a theoretical framework and review of experiments. Ecol Monogr 70:171-207.

Dale VH, Crisafulli CM, Swanson FJ. 2005. 25 years of ecological change at Mount St. Helens. Science 308:961-2.

de la Cretaz AL, Kelty MJ. 1999. Establishment and control of hay-scented fern: a native invasive species. Biol Invasions $1: 223-36$

de la Cretaz AL, Kelty MJ. 2002. Development of tree regeneration in fern-dominated forest understories after reduction of deer browsing. Restor Ecol 10:416-26. 
De Long JR, Kardol P, Sundqvist MK, Veen GF, Wardle DA. 2015. Plant growth response to direct and indirect temperature effects varies by vegetation type and elevation in a subarctic tundra. Oikos 124:772-83.

DenOuden J. 2000. The role of bracken (Pteridium aquilinum) in forest dynamics. Dissertation for the degree of Doctor of Sciences, Ph.D. Netherlands: Wageningen University.

Dolling AHU. 1996. Interference of bracken (Pteridium aquilinum L Kuhn) with Scots pine (Pinus sylvestris L) and Norway spruce (Picea abies L Karst) seedling establishment. For Ecol Manag 88:227-35.

Ellenberg H. 1996. Vegetation Mitteleuropas mit den Alpen in ökologischer, dynamischer und historischer Sicht. Stuttgart: Ulmer. p 1096p.

Fischer A. 1999. Die Entwicklung von Wald-Biozönosen nach Sturmwurf. Weinheim: Wiley.

Frehner M, Wasser B, Schwitter R. 2005. Nachhaltigkeit im Schutzwald (Projekt NaiS) - Bundesamt für Umwelt BAFU. Bern.

George LO, Bazzaz FA. 1999a. The fern understory as an ecological filter: emergence and establishment of canopy-tree seedlings. Ecology 80:833-45.

George LO, Bazzaz FA. 1999b. The fern understory as an ecological filter: growth and survival of canopy-tree seedlings. Ecology 80:846-56.

George LO, Bazzaz FA. 2003. The herbaceous layer as a filter determining spatial pattern in forest tree regeneration. In: Gilliam FSR, Eds. The herbaceous layer in forests of eastern North America. New York: Oxford University Press, pp 26582.

Gilliam FS. 2007. The ecological significance of the herbaceous layer in temperate forest ecosystems. Bioscience 57:845-58.

Hart SA, Chen HYH. 2006. Understory vegetation dynamics of North American boreal forests. Crit Rev Plant Sci 25:381-97.

Henne PD, Elkin C, Colombaroli D, Samartin S, Bugmann H, Heiri O, Tinner W. 2013. Impacts of changing climate and land use on vegetation dynamics in a Mediterranean ecosystem: insights from paleoecology and dynamic modeling. Landsc Ecol 28:819-33.

Hickler T, Vohland K, Feehan J, Miller PA, Smith B, Costa L, Giesecke T, Fronzek S, Carter TR, Cramer W, Kuhn I, Sykes MT. 2012. Projecting the future distribution of European potential natural vegetation zones with a generalized, tree species-based dynamic vegetation model. Glob Ecol Biogeogr 21:50-63.

Hiltbrunner E, Aerts R, Bühlmann T, Huss-Danell K, Magnusson B, Myrold DD, Reed SC, Sigurdsson BD, Körner C. 2014. Ecological consequences of the expansion of N-2-fixing plants in cold biomes. Oecologia 176:11-24.

Horsley S. 1993. Mechanisms of interference between hayscented fern and black-cherry. Can J For Res 23:2059-69.

IPCC. 2013. Climate Change 2013: The Physical Science Basis. Contribution of Working Group I to the Fifth Assessment Report of the Intergovernmental Panel on Climate Change. In: Stocker TF, Qin D, Plattner G-K, Tignor M, Allen SK, Boschung J, Nauels A, Xia Y, Bex V, Midgley PM, Eds. Cambridge, United Kingdom and New York, NY, USA: Cambridge University Press.

Jules MJ, Sawyer JO, Jules ES. 2008. Assessing the relationships between stand development and understory vegetation using a 420-year chronosequence. For Ecol Manag 255:2384-93.
Kellomäki S, Väisänen H. 1991. Application of a gap model for the simulation of forest ground vegetation in boreal conditions. For Ecol Manag 42:35-47.

Koop H, Hilgen P. 1987. Forest dynamics and regeneration mosaic shifts in unexploited beech (Fagus-Sylvatica) stands at Fontainebleau (France). For Ecol Manag 20:135-50.

Kowalenko CG. 2003. An evaluation of estimating and indexing methods to simplify the determination of management treatment effects on raspberry yields. Can J Plant Sci 83:141-7.

Kramer K, Brang P, Bachofen H, Bugmann H, Wohlgemuth T. 2014. Site factors are more important than salvage logging for tree regeneration after wind disturbance in Central European forests. For Ecol Manage 331:116-28.

Kupferschmid AD, Bugmann H. 2005. Effect of microsites, logs and ungulate browsing on Picea abies regeneration in a mountain forest. For Ecol Manag 205:251-65.

Kupferschmid AD, Wasem U, Bugmann H. 2015. Browsing regime and growth response of Abies alba saplings planted along light gradients. Eur J Forest Res 134:75-87.

Laurent JM, Bar-Hen A, Francois L, Ghislain M, Cheddadi R. 2004. Refining vegetation simulation models: From plant functional types to bioclimatic affinity groups of plants. J Veg Sci 15:739-46.

Li MH, Du Z, Pan HL, Yan CF, Xiao WF, Lei JP. 2012. Effects of neighboring woody plants on target trees with emphasis on effects of understorey shrubs on overstorey physiology in forest communities: a mini-review. Commun Ecol 13:117-28.

Lieffers V, Macdonald S, Hogg E. 1993. Ecology of and control strategies for Calamagrostis canadensis in boreal forest sites. Can J For Res 23:2070-7.

Maguire DA, Forman RTT. 1983. Herb cover effects on tree seedling patterns in a mature hemlock-hardwood forest. Ecology 64:1367-80.

Maher EL, Germino MJ, Hasselquist NJ. 2005. Interactive effects of tree and herb cover on survivorship, physiology, and microclimate of conifer seedlings at the alpine tree-line ecotone. Can J For Res 35:567-74.

McCarthy BC. 2003. The herbaceous layer of eastern old-growth deciduous forests. In: Gilliam FS, Roberts MR, Eds. The herbaceous layer in forests of eastern North America. New York: Oxford University Press, pp 163-76.

McKenzie D, Raymond CL, Cushman SA. 2009. Modeling understory vegetation and its response to fire. In: Millspaugh JJ, Thompson FR, Eds. Models for planning wildlife conservation in large landscapes. San Diego: Academic Press, pp 391-414.

Mladenoff DJ. 2004. LANDIS and forest landscape models. Ecol Model 180:7-19.

Monsi M, Saeki T. 2005. On the factor light in plant communities and its importance for matter production. Ann Bot 95:549-67.

Nabuurs GJ. 1996. Quantification of herb layer dynamics under tree canopy. For Ecol Manag 88:143-8.

Niering W, Goodwin R. 1974. Creation of relatively stable shrublands with herbicides-arresting succession on rights-of-way and pastureland. Ecology 55:784-95.

Nieto-Lugilde D, Lenoir J, Abdulhak S, Aeschimann D, Dullinger S, Gegout JC, Guisan A, Pauli H, Renaud J, Theurillat JP, Thuiller W, Van Es J, Vittoz P, Willner W, Wohlgemuth T, Zimmermann NE, Svenning JC. 2015. Tree cover at fine and coarse spatial grains interacts with shade tolerance to shape 
plant species distributions across the Alps. Ecography 38:57889.

Nilsson M-C, Wardle DA. 2005. Understory vegetation as a forest ecosystem driver: evidence from the northern Swedish boreal forest. Front Ecol Environ 3:421-8.

Oliver C. 1981. Forest development in north-America following major disturbances. For Ecol Manag 3:153-68.

Ott E, Frehner M, Frey HU, Lüscher P. 1997. Gebirgsnadelwälder: ein praxisorientierter Leitfaden für eine standortgerechte Waldbehandlung. Bern: P. Haupt Verlag. p 288p.

Pitman JI. 2000. Absorption of photosynthetically active radiation, radiation use efficiency and spectral reflectance of bracken [Pteridium aquilinum (L.) Kuhn] canopies. Ann Bot 85:101-11.

Priewasser K. 2013. Factors influencing tree regeneration after windthrow in Swiss forests. Dissertation for the degree of Doctor of Sciences, Ph.D. Thesis No. 21011. ETH Zurich.

Provendier D, Balandier P. 2008. Compared effects of competition by grasses (Graminoids) and broom (Cytisus scoparius) on growth and functional traits of beech saplings (Fagus sylvatica). Ann For Sci 65:510.

R Development Core Team. 2014. R: A language and environment for statistical computing. R Foundation for Statistical Computing, Vienna, Austria

Raich JW, Russell AE, Vitousek PM. 1997. Primary productivity and ecosystem development along an elevational gradient on Mauna Loa, Hawai'i. Ecology 78:707-21.

Royo AA, Carson WP. 2006. On the formation of dense understory layers in forests worldwide: consequences and implications for forest dynamics, biodiversity, and succession. Can J For Res 36:1345-62.

Royo AA, Carson WP. 2008. Direct and indirect effects of a dense understory on tree seedling recruitment in temperate forests: habitat-mediated predation versus competition. Can J For Res 38:1634-45.

Sato H, Itoh A, Kohyama T. 2007. SEIB-DGVM: A new dynamic global vegetation model using a spatially explicit individualbased approach. Ecol Model 200:279-307.

Sayer U, Reif A. 1999. Entwicklung der Vegetation im überregionalen Vergleich. Fischer A editor. Die Entwicklung von Wald-Biozonosen nach Sturmwurf. Weinheim: Wiley, pp 146-68.

Schumacher S. 2004. The role of large-scale disturbances and climate for the dynamics of forested landscapes in the Euro- pean Alps. Dissertation for the degree of Doctor of Sciences, Ph.D. Thesis No. 15573. ETH Zurich.

Schumacher S, Bugmann H, Mladenoff DJ. 2004. Improving the formulation of tree growth and succession in a spatially explicit landscape model. Ecol Model 180:175-94.

Schumacher S, Reineking B, Sibold J, Bugmann H. 2006. Modeling the impact of climate and vegetation on fire regimes in mountain landscapes. Landsc Ecol 21:539-54.

Schwitter R, Sandri A, Bebi P, Wohlgemuth T, Brang P. 2015. Lehren aus Vivian für den Gebirgswald - im Hinblick auf den nächsten Sturm. Schweizerische Zeitschrift für Forstwesen 166:159-67.

Shropshire C, Wagner RG, Bell FW, Swanton CJ. 2001. Light attenuation by early successional plants of the boreal forest. Can J For Res 31:812-23.

Smith B, Prentice IC, Sykes MT. 2001. Representation of vegetation dynamics in the modelling of terrestrial ecosystems: comparing two contrasting approaches within European climate space. Glob Ecol Biogeogr 10:621-37.

Stromayer KAK, Warren RJ. 1997. Are overabundant deer herds in the eastern United States creating alternate stable states in forest plant communities? Wildl Soc Bull 25:227-34.

Temperli C, Bugmann H, Elkin C. 2013. Cross-scale interactions among bark beetles, climate change, and wind disturbances: a landscape modeling approach. Ecol Monogr 83:383-402.

Thrippleton T, Dolos K, Perry GLW, Groeneveld J, Reineking B. 2014. Simulating long-term vegetation dynamics using a forest landscape model: the post-Taupo succession on $\mathrm{Mt}$ Hauhungatahi, North Island, New Zealand. N Z J Ecol 38:2643.

Turner MG, Dale VH, Everham EH. 1997. Fires, hurricanes, and volcanoes: comparing large disturbances. Bioscience 47:75868.

Turner MG, Gardner RH, O'Neill RV. 2001. Landscape ecology in theory and practice: pattern and process. New York: Springer.

Walker LR, Wardle DA, Bardgett RD, Clarkson BD. 2010. The use of chronosequences in studies of ecological succession and soil development. J Ecol 98:725-36.

Weisberg PJ, Bugmann H. 2003. Forest dynamics and ungulate herbivory: from leaf to landscape. For Ecol Manag 181:1-12.

Weisberg PJ, Hadorn C, Bugmann H. 2003. Predicting understorey vegetation cover from overstorey attributes in two temperate mountain forests. Forstwissenschaftliches Centralblatt 122:273-86. 